\title{
Isolation and Structure Determination of Three New Ceramides from the Starfish Distolasterias nipon
}

\author{
Jung-Rae Rho* and Young Hwan Kim ${ }^{\dagger}$ \\ Dept. of Marine Information Science, Kunsan National University, Kunsan, Jeonbuk 573-701, Korea \\ *E-mail:jrrho@kunsan.ac.kr \\ ${ }^{\dagger}$ Proteomics Team, Korea Basic Science Institute, Daejeon 305-333, Korea \\ Received May 6, 2005
}

Key Words : Ceramide, Distolasterias nipon, 2D NMR, FABMS/MS

Starfishes have been reported to contain a number of glycosphingolipids and sterol compounds with unconventional side chain. ${ }^{1-3}$ Some glycosphingolipids have exhibited cytotoxicity, histidine decarboxylate inhibition, DNA topoisomerase I inhibition, moderate wound-healing activity and induced apoptotic DNA damage and cell death in mammalian cell lines. ${ }^{4-7}$ In our search for biologically active and structurally novel lipids from marine organisms, we recently isolated mixtures of several sphingolipids from the starfish Distolasterias nipon collected off the coast of East Sea, Korea. Further HPLC of the fraction resulted in the purification of three new ceramides which are composed of the aglycone part of glycosphingolipids. In this paper we report the isolation and structure determination of new ceramides (compound 1, 2, and 3) isolated from the starfish D. nipon.

Compound 1 was isolated as a white amorphous solid which determined for $\mathrm{C}_{35} \mathrm{H}_{65} \mathrm{NO}_{4}$ by high resolution FABMS. The IR spectrum displayed absorption bands at 3314 (hydroxyl), 1650, and $1540 \mathrm{~cm}^{-1}$ (amide). The ${ }^{1} \mathrm{H}$ NMR spectrum showed highly overlapped signals at $\delta 1.29-1.31$, indicative of long aliphatic carbon chain, and the ${ }^{13} \mathrm{C} N M R$ spectrum suggested the presence of one carbonyl carbon, four carbons attached to heteroatoms, and six olefinic carbons on the basis of their characteristic chemical shifts. All these information of $\mathbf{1}$ allowed us to deduce a ceramide nature containing three double bonds. This is also supported by the ${ }^{1} \mathrm{H}$ NMR spectrum measured in pyridine- $d_{5}$ which showed a downfield proton signal at $\delta 8.38(\mathrm{~d}, J=8.8 \mathrm{~Hz})$ corresponding to the secondary amide proton (Table 1 ).

The main framework of compound 1 was established by extensive 2D NMR techniques. The methine proton at $\delta$ 3.84 , connected to a nitrogen-bearing carbon, was coupled to the nonequivalent oxymethylene protons $(\mathrm{H}-1)$ at $\delta 3.66$ and

Table 1. Spectral data for compound $\mathbf{1}$ in $\mathrm{MeOH}-\mathrm{d}_{4}$ and pyridine- $\mathrm{d}_{5}$

\begin{tabular}{|c|c|c|c|c|}
\hline position & ${ }^{1} \mathrm{H}\left(\mathrm{MeOH}-\mathrm{d}_{4}\right)$ & ${ }^{13} \mathrm{C}\left(\mathrm{MeOH}-\mathrm{d}_{4}\right)$ & $\mathrm{COSY}\left(\mathrm{MeOH}-\mathrm{d}_{4}\right)$ & ${ }^{1} \mathrm{H}$ (pyridine- $\mathrm{d}_{5}$ ) \\
\hline 1a & $3.66(\mathrm{dd}, 11.2,3.9)$ & $61.9, \mathrm{t}$ & $1 b, 2$ & $4.24(\mathrm{dd}, 10.3,2.9)$ \\
\hline $1 b$ & $3.78(\mathrm{dd}, 11.2,5.4)$ & & $1 \mathrm{a}, 2$ & $4.49(\mathrm{dd}, 10.3,3.9)$ \\
\hline 2 & $3.84(\mathrm{ddd}, 7.3,5.4,3.9)$ & $56.0, \mathrm{~d}$ & $3,1 \mathrm{a}, 1 \mathrm{~b}$ & $4.71(\mathrm{~m})$ \\
\hline 3 & $4.09(\mathrm{dd}, 7.3,7.3)$ & 73.3, d & 2,4 & $4.86(\mathrm{~m})$ \\
\hline 4 & $5.50(\mathrm{dd}, 15.6,7.3)$ & $131.5, \mathrm{~d}$ & 3,5 , & $6.09(\mathrm{dd}, 15.6,6.3)$ \\
\hline 5 & $5.72(\mathrm{dt}, 15.6,6.4)$ & 134.1, d & 4,6 & $6.00(\mathrm{dd}, 15.6,5.9)$ \\
\hline 6 & $2.10(\mathrm{dt}, 6.4,7.3)$ & $33.5, \mathrm{t}$ & 5,7 & $2.17(\mathrm{~m})$ \\
\hline 7 & $2.20($ dt. $7.3,7.3)$ & $28.7, \mathrm{t}$ & 6,8 & $2.22(\mathrm{~m})$ \\
\hline 8 & $5.35(\mathrm{t}, 7.3)$ & $130.3, \mathrm{~d}$ & 7 & $5.52(t, 6.8)$ \\
\hline 9 & & 135.2, s & & \\
\hline 10 & $6.02(\mathrm{~d}, 15.6)$ & 136.1, d & 11 & $6.21(\mathrm{~d}, 15.1)$ \\
\hline 11 & $5.54(\mathrm{dt}, 15.6,7.3)$ & $128.5, \mathrm{~d}$ & 10,12 & $5.65(\mathrm{dt}, 15.1,6.8)$ \\
\hline 12 & $2.08(\mathrm{dt}, 7.3,6.8)$ & $34.0, \mathrm{t}$ & & $2.10(\mathrm{~m})$ \\
\hline $13-17$ & $1.29-1.31(\mathrm{~m})$ & $23.7-33.1, \mathrm{t}$ & & $1.24-1.34(\mathrm{~m})$ \\
\hline 18 & $0.89(\mathrm{t}, 6.9)$ & $14.4, \mathrm{q}$ & & $0.86(t, 7.3)$ \\
\hline 19 & $1.71(\mathrm{~s})$ & $12.8, \mathrm{q}$ & & $1.76(\mathrm{~s})$ \\
\hline NH & & & & $8.38(\mathrm{~d}, 8.8)$ \\
\hline $1^{\prime}$ & & 177.2, s & & \\
\hline $2^{\prime}$ & $3.99(\mathrm{dd}, 7.8,3.9)$ & $73.0, \mathrm{~d}$ & $3^{\prime} \mathrm{a}, 3^{\prime} \mathrm{b}$ & $4.62(\mathrm{t}, 2.9)$ \\
\hline 3'a & $1.55(\mathrm{~m})$ & $35.9, \mathrm{t}$ & $2^{\prime}, 3^{\prime} \mathrm{b}$ & $2.17(\mathrm{~m})$ \\
\hline $3^{\prime} \mathrm{b}$ & $1.71(\mathrm{~m})$ & & $2^{\prime}, 3^{\prime} \mathrm{a}$ & $2.06(\mathrm{~m})$ \\
\hline $4^{\prime}-15^{\prime}$ & $1.29-1.39(\mathrm{~m})$ & $23.7-33.1, \mathrm{t}$ & & $1.24-1.34(\mathrm{~m})$ \\
\hline $16^{\prime}$ & $0.89(\mathrm{t}, 6.9)$ & $14.4, \mathrm{q}$ & & $0.85(\mathrm{t}, 7.3)$ \\
\hline
\end{tabular}

Data were recorded at $500 \mathrm{MHz}$ for ${ }^{1} \mathrm{H}$ and $125 \mathrm{MHz}$ for ${ }^{13} \mathrm{C}$. Assignments were made by COSY, TOCSY, HSQC, and HMBC experiments. 
3.78 , and another oxymethine proton $(\mathrm{H}-3)$ at $\delta 4.09$ which in turn was coupled to the olefinic proton (H-4) at $\delta 5.50$ in the COSY experiment. The sequential COSY correlations from $\mathrm{H}-4$ to $\mathrm{H}-8$ and the HMBC correlations of the methyl proton $(\mathrm{H}-19)$ at $\delta 1.71$ with three neighboring olefinic carbons at $\delta 130.3(\mathrm{C}-8, \mathrm{CH}), 135.2(\mathrm{C}-9, \mathrm{C})$ and 136.1 (C$10, \mathrm{CH})$ revealed that one double bond was connected to a diene with a branched methyl at the C-9 position via an ethylene group. The existence of the conjugated diene at $\mathrm{C}-8$ was also confirmed by the coupling between $\mathrm{H}-10$ and $\mathrm{H}-11$ and the UV spectrum $\left(\lambda_{\max }=235 \mathrm{~nm}\right.$ in $\left.\mathrm{MeOH}\right)$. The large coupling constants $(J=15.6,15.6 \mathrm{~Hz})$ for the olefinic protons in positions $\mathrm{C}-4,-5$ and $\mathrm{C}-10,-11$ and the NOE observations between $\mathrm{H}-8$ and $\mathrm{H}-10, \mathrm{H}-19$ and $\mathrm{H}-7$ indicated that three double bonds had the $(E)$ configurations. Further analyses of COSY and HMBC experiments showed the existence of $\alpha$-hydroxy fatty acyl chain within the compound 1.

In order to determine the length of two alkyl chains of the ceramide, $\mathbf{1}$ was methanolyzed to afford a fatty acid methyl ester and a sphingosine. The methyl ester part was characterized to be methyl (2R)-hydroxyhexadecanoate (4) by analysis of GC-MS $\left(m / z=286\left[\mathrm{M}^{+}\right]\right)$and the value of optical rotation, $[\alpha]_{\mathrm{D}}^{25}-3.8^{\circ}\left(\mathrm{c} 0.06, \mathrm{CHCl}_{3}\right)$, which is very close to that of similar molecules. ${ }^{5,8}$ On the other hand, the sphingosine unit was readily recognized as $\mathrm{C}_{19} \mathrm{H}_{35} \mathrm{NO}_{2}$

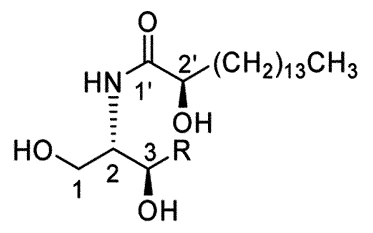

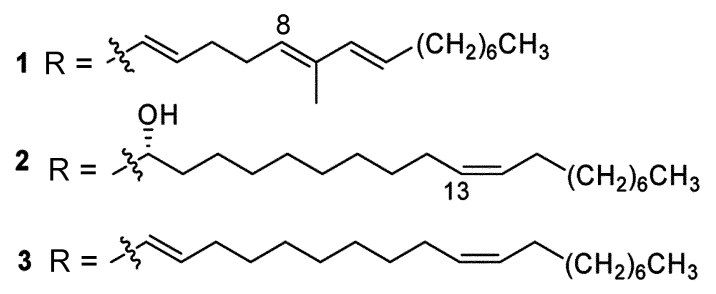

4<smiles>CCCCCCCCCCCCCCC(O)C(=O)OC</smiles>

1 a<smiles>CCC=CC(C)=CCCC=CC(O)[C@@H](N)CO</smiles>

2a<smiles>CCCC=CCCCCCCCC[C@@H](O)[C@H](N)CO</smiles>

3a<smiles>CCCC=CCCCCCCC=CC(O)[C@@H](N)CO</smiles>

Figure 1. The molecular structure of compounds 1, 2 and 3 and their derivatives. according to a molecular ion $[\mathrm{M}+\mathrm{H}]^{+}$observed at $\mathrm{m} / \mathrm{z}=310$ by FAB-MS. In addition, the sphingosine unit was acetylated with $\mathrm{Ac}_{2} \mathrm{O} /$ pyridine for the determination of stereochemistry of the asymmetric centers at the C-2 and -3 positions. As a result, the key proton chemical shifts and coupling constants were very close to those of triacetyl Derythro-sphingosine and also the specific rotation was in agreement with that of the $(2 S, 3 R, 4 E)$-sphingosine unit reported in literature. ${ }^{2,9}$ Accordingly, $\mathbf{1}$ was determined as (2'R)-hydroxy- $N$-palmitoyl-D-erythro-(2S,3R)-9-methyloctadecasphinga- $(4 E, 8 E, 10 E)$-trienine (Figure 1).

Compound 2 was given as a colorless amorphous powder and its molecular formula was established as $\mathrm{C}_{38} \mathrm{H}_{75} \mathrm{NO}_{5}$ by HRFAB-MS. Analyses of the NMR, IR, and HRFAB-MS spectra data of $\mathbf{2}$ clearly showed that it was a ceramide containing one double bond. The methanolysis on $\mathbf{2}$ was performed to yield a fatty acid methyl ester and a long chain phytosphingosine moiety with an oxymethine proton (H-4) at $\delta 3.51$ instead of an olefinic proton. The methyl ester was identified as methyl $(2 R)$-hydroxyhexadecanoate (4) and the phytosphingosine component (2a) was revealed to be a docosene derivative on the basis of the molecular ion peak at $m / z=372[\mathrm{M}+\mathrm{H}]^{+}$of FAB-MS and the ${ }^{1} \mathrm{H}$ NMR spectral data. Compound 2a was thought to possess one olefinic group somewhere in the long carbon chain, since the olefinic protons were only coupled to the protons overlapped at $\delta$ 1.29-1.31 region in the COSY spectrum. The location and geometry of the double bond were determined as follows. The detailed FABMS/MS showed a remarkable fragment ion peaks at $m / z=218$ and 273 due to cleavage of bonds at the allylic position of double bond, indicating that the double bond in 2a is positioned at C-13 (Figure 2). Furthermore, the geometry of this double bond can be determined by the ${ }^{13} \mathrm{C}$ chemical shift $(\delta 28.2)$ of the allylic carbon, which was commonly observed in the $(Z)$ configurations. ${ }^{10}$ On the other hand, stereochemistry of C-2 to C-4 in the phytosphingosine was established in the same way as 1 . The comparison of ${ }^{1} \mathrm{H}$ NMR data and the optical rotation of tetraacetyl derivative of the base with those of similar compounds allowed us to propose the $2 S, 3 S, 4 R$ configuration ${ }^{11}$ and the gross structure of 2 was assigned to be (2'R)-hydroxy- $N$-palmitoyl-Derythro-( $2 S, 3 S, 4 R)$-docosasphinga-(13Z)-monoenine.

Finally, compound $\mathbf{3}$ was also obtained as a white solid. Its molecular formula was assigned as $\mathrm{C}_{38} \mathrm{H}_{73} \mathrm{NO}_{4}$ by HRFABMS. The only difference between $\mathbf{2}$ and $\mathbf{3}$ was an appearance of one double bond by dehydration of 2 . This double bond was obviously confirmed as (4E)-alkene moiety from the COSY correlations from $\mathrm{H}-2$ to $\mathrm{H}-5$ and the large proton coupling constants $\left(J_{45}=15.1 \mathrm{~Hz}\right)$. On methanolysis of $\mathbf{3}$, the methyl ester was recognized as a common methyl $(2 R)$ hydroxyhexadecanoate (4) and the sphingosine part was given as a docosadiene amino alcohol corresponding to a molecular ion peak at $m / z=354[\mathrm{M}+\mathrm{H}]^{+}$by FAB-MS. Another double bond in the long chain sphingosine was assigned as (13Z) configuration by the FAB-MS/MS analyses and carbon chemical shifts in the same way as $\mathbf{2}$ (Figure 2). Also the ${ }^{1} \mathrm{H}$ NMR data and the optical rotation of 


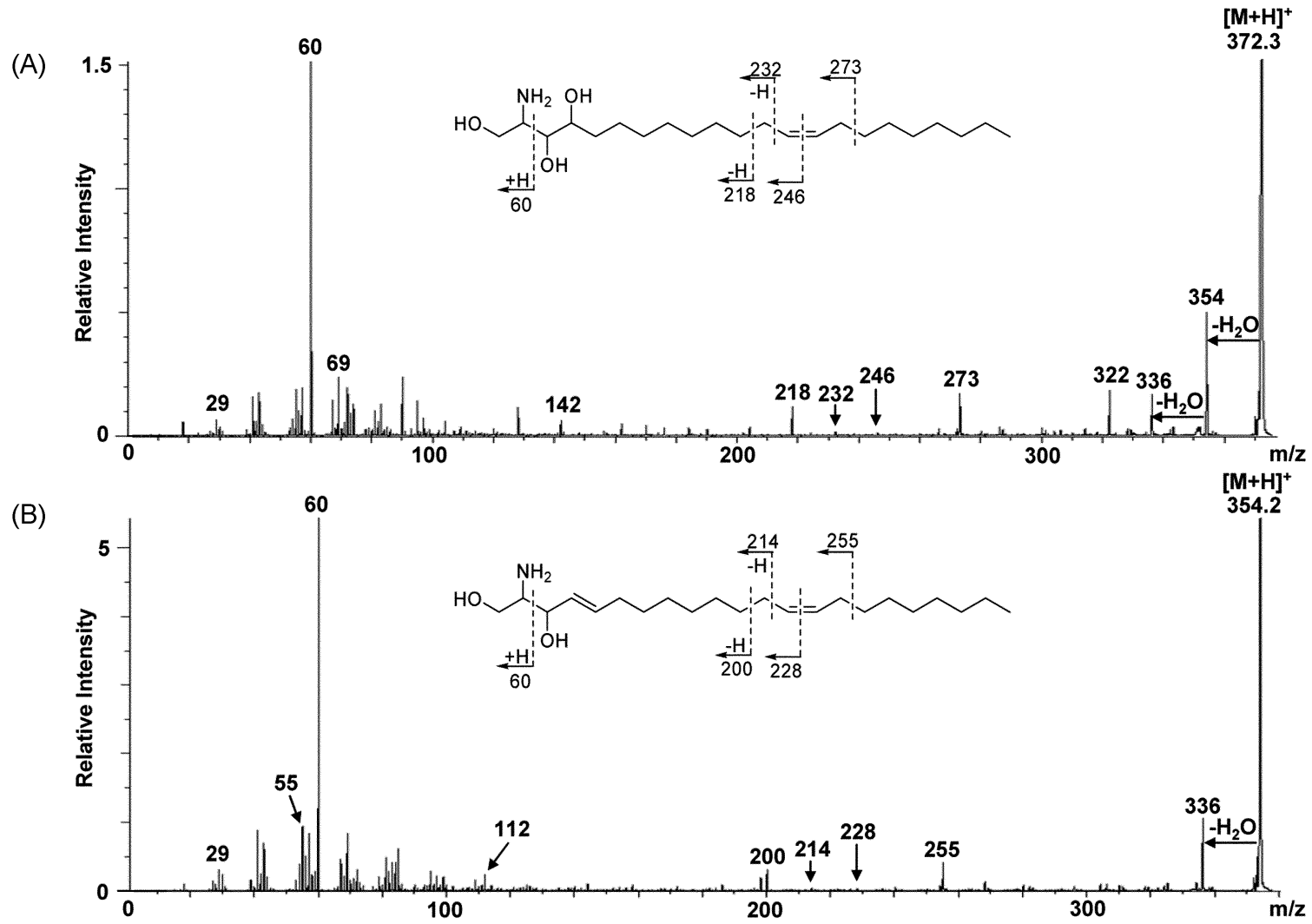

Figure 2. MS/MS spectra and fragmentations of $\mathbf{2 a}(\mathrm{A})$ and $\mathbf{2 b}(\mathrm{B})$.

the acetylated sphingosine derivative agreed well with those of 1 . All these data allowed this compound to be defined as (2'R)-hydroxy- $N$-palmitoyl-D-erythro- $(2 S, 3 R)$-docosasphinga-(4E,13Z)-dienine.

Compounds 1, 2, and $\mathbf{3}$ are, to the best of our knowledge, new ceramides. For the biological evaluation of them, activity tests are under examination. While several glycosphingolipids from starfish have been studied, the isolation and characterization of ceramides has not been well known.

\section{Experimental Procedures}

Optical rotations were measured on a JASCO DIP-1000 digital polarimeter. UV spectra were obtained in $\mathrm{MeOH}$ using a Shimadzu UV-1650PC and IR spectra were measured on a Mattson Galaxy spectrometer. All NMR spectra were recorded in $\mathrm{CD}_{3} \mathrm{OD}$ solution on a Varian UNITY 500 spectrometer. Chemical shifts of proton and carbon spectra were reported in reference to residual solvent peaks at $3.30 \mathrm{ppm}$ and $49.0 \mathrm{ppm}$, respectively. GC-MS experiments were done on a Hewlett Packard HP6890. FABMS and MS/MS spectra were obtained on JEOL JMSHX110/110A four sector tandem mass spectrometer. The details about mass spectrometric methods were described elsewhere. $^{12}$

Extraction and Isolation. The starfish Distolasterias nipon was collected at Donghae in the East Sea of Korea. The frozen organism $(1.2 \mathrm{Kg})$ was cut into small pieces and extracted twice with $\mathrm{MeOH}$ at room temperature. The methanolic extract ( $c$. $140 \mathrm{~g}$ ) was partitioned between $\mathrm{MeOH}$ and $n$-hexane. The $n$-hexane layer was subjected to silica gel flash column chromatography eluting with the solvents of increasing polarity (hexane, EtOAc, acetone, and $\mathrm{MeOH})$. The acetone-soluble fraction ( $c$. $800 \mathrm{mg}$ ) was separated by reversed-phase HPLC (YMC ODS-A column, $250 \times 10 \mathrm{~mm} \mathrm{ID)}$ eluting with $100 \% \mathrm{MeOH}$ to give eight fractions. The fractions containing compounds 1, 2, and $\mathbf{3}$ were further purified on reversed-phase HPLC using $\mathrm{CH}_{3} \mathrm{CN}-\mathrm{MeOH}(2: 8)$ to afford compounds 1 (12 mg), 2 (34 $\mathrm{mg}$ ), and 3 (14 $\mathrm{mg}$ ).

Methanolysis and Acetylation. Each compound (3 mg) was heated with $3 \mathrm{~mL}$ of $1 \mathrm{~N} \mathrm{HCl}$ in $80 \% \mathrm{MeOH}$ at $70{ }^{\circ} \mathrm{C}$ overnight in a sealed small vial. The reaction mixture was evaporated and then partitioned with $n$-hexane and $\mathrm{MeOH}$. The hexane layer was concentrated to afford the methyl ester. The sphingosine obtained from the $\mathrm{MeOH}$ layer was further acetylated with $\mathrm{Ac}_{2} \mathrm{O}$ /pyridine $(1: 4,0.5 \mathrm{~mL})$ at 80 ${ }^{\circ} \mathrm{C}$ for $2 \mathrm{hrs}$. After walk-up with $\mathrm{MeOH}$ and solvent drying procedures, the mixture was partitioned into $\mathrm{CH}_{2} \mathrm{Cl}_{2}$ and $\mathrm{H}_{2} \mathrm{O}$. The $\mathrm{CH}_{2} \mathrm{Cl}_{2}$ layer was subjected to silica column to furnish an acetyl derivative of sphingosine.

Compound 1: $[\alpha]_{\mathrm{D}}^{25}+3.30^{\circ}$ (c 0.21, MeOH); UV $(\mathrm{MeOH}) \lambda_{\max }(\log \varepsilon) 235 \mathrm{~nm}$ (4.53); IR (KBr) 3317, 2918, 2849, 1650, 1540, 1450, $1409 \mathrm{~cm}^{-1} ;{ }^{1} \mathrm{H}$ and ${ }^{13} \mathrm{C}$ NMR data were given in Table 1; HRFAB-MS [M + Na] ${ }^{+} m / z 586.4808$ $(\Delta-0.4 \mathrm{mmu})$. 
Acetyl derivative of 1a: $[\alpha]_{\mathrm{D}}^{25}-6.6^{\circ}\left(\mathrm{c} 0.13, \mathrm{CHCl}_{3}\right) ;{ }^{1} \mathrm{H}$ NMR $\left(\mathrm{CDCl}_{3}, 500 \mathrm{MHz}\right), \delta 5.79(1 \mathrm{H}, \mathrm{ddd}, J=15.6,6.8,6.8$ Hz, H-5), 5.68 (1H, d, $J=9.3 \mathrm{~Hz},-\mathrm{NH}), 5.38$ (1H, dd, $J=$ $15.6,6.8 \mathrm{~Hz}, \mathrm{H}-4), 5.28$ (1H, dd, $J=6.8,6.8 \mathrm{~Hz}, \mathrm{H}-3), 4.44$ (1H, m, H-2), 4.31 (1H, dd, $J=11.2,5.9 \mathrm{~Hz}, \mathrm{H}-1), 4.04(1 \mathrm{H}$, $\mathrm{dd}, J=11.2,3.9 \mathrm{~Hz}, \mathrm{H}-1), 2.07$ (6H, s, $\left.\mathrm{CH}_{3} \mathrm{COO}\right), 1.99(3 \mathrm{H}$, $\mathrm{s}, \mathrm{CH}_{3} \mathrm{CONH}$ ).

Compound 2: $[\alpha]_{\mathrm{D}}^{25}+8.63^{\circ}$ (c $\left.0.21, \mathrm{MeOH}\right)$; IR (KBr) $3313,2919,2850,1634,1545,1457 \mathrm{~cm}^{-1}$; ${ }^{1} \mathrm{H}$ NMR $\left(\mathrm{CD}_{3} \mathrm{OD}, 500 \mathrm{MHz}\right), \delta 5.33(2 \mathrm{H}, \mathrm{t}, J=4.9 \mathrm{~Hz}, \mathrm{H}-14,15)$, 4.09 (1H, ddd, $J=4.5,4.5,5.9 \mathrm{~Hz}, \mathrm{H}-2), 4.02(1 \mathrm{H}, \mathrm{dd}, J=$ 7.3, $\left.3.9 \mathrm{~Hz}, \mathrm{H}-2^{\prime}\right), 3.74$ (2H, d, $\left.J=4.5 \mathrm{~Hz}, \mathrm{H}-1\right), 3.56(1 \mathrm{H}$, $\mathrm{dd}, J=5.9,5.9 \mathrm{~Hz}, \mathrm{H}-3), 3.51(1 \mathrm{H}, \mathrm{ddd}, J=8.7,5.9,2.9 \mathrm{~Hz}$, H-4), 2.02 (4H, m, H-13, 16), 1.73 (1H, m, H-3'), 1.64 (1H, m, H-5), 1.58 (1H, m, H-3'), 1.41 (1H, m, H-5), 1.42-1.28 $\left(48 \mathrm{H}, \mathrm{m},-\mathrm{CH}_{2}-\right), 0.89(6 \mathrm{H}, \mathrm{t}, J=6.4 \mathrm{~Hz}, \mathrm{H}-16,18) ;{ }^{13} \mathrm{C}$ $\mathrm{NMR}\left(\mathrm{CD}_{3} \mathrm{OD}, 125 \mathrm{MHz}\right) \delta 176.9\left(\mathrm{C}, \mathrm{C}-1^{\prime}\right), 130.8(\mathrm{CH}, \mathrm{C}-$ 14, 15), 76.0 (CH, C-3), 73.2 (CH, C-4), 72.9 (CH, C-2'), $35.0\left(\mathrm{CH}_{2}, \mathrm{C}-3{ }^{\prime}\right), 33.0\left(\mathrm{CH}_{2}, \mathrm{C}-5\right), 30.9-30.5\left(\mathrm{CH}_{2},-\mathrm{CH}_{2}-\right)$, $28.2\left(\mathrm{CH}_{2}, \mathrm{C}-13,16\right), 14.4\left(\mathrm{CH}_{3}, \mathrm{C}-16\right.$ ', 18$)$; HRFAB-MS $[\mathrm{M}+\mathrm{Na}]^{+} \mathrm{m} / z 648.5543(\Delta+0.2 \mathrm{mmu})$.

Acetyl derivative of $2 \mathrm{a}:[\alpha]_{\mathrm{D}}^{25}=+12.6^{\circ}\left(\mathrm{c} 0.09, \mathrm{CHCl}_{3}\right)$; ${ }^{1} \mathrm{H} \mathrm{NMR}\left(\mathrm{CDCl}_{3}, 500 \mathrm{MHz}\right), \delta 5.74(1 \mathrm{H}, \mathrm{d}, J=9.3 \mathrm{~Hz}, N \mathrm{H})$, $5.11(1 \mathrm{H}, \mathrm{dd}, J=8.3,2.9 \mathrm{~Hz}, \mathrm{H}-3), 4.94(1 \mathrm{H}, \mathrm{dd}, J=9.7,2.9$ $\mathrm{Hz}, \mathrm{H}-4), 4.47$ (1H, m, H-2), 4.30 (1H, dd, $J=11.2,4.9 \mathrm{~Hz}$, $\mathrm{H}-1), 4.00$ (1H, dd, $J=11.2,3.4 \mathrm{~Hz}, \mathrm{H}-1), 2.08$ (3H, s, $\left.\mathrm{CH}_{3} \mathrm{COO}\right), 2.05$ (6H, s, $\left.\mathrm{CH}_{3} \mathrm{COO}\right), 2.03$ (3H, s, $\left.\mathrm{CH}_{3} \mathrm{CONH}\right)$.

Compound 3: $[\alpha]_{\mathrm{D}}^{25}+4.98^{\circ}$ (c $\left.0.30, \mathrm{MeOH}\right)$; IR (KBr) $3313,2919,2850,1634,1545,1457 \mathrm{~cm}^{-1}$; ${ }^{1} \mathrm{H}$ NMR $\left(\mathrm{CD}_{3} \mathrm{OD}, 500 \mathrm{MHz}\right), \delta 5.70(1 \mathrm{H}, \mathrm{dt}, J=15.1,6.8 \mathrm{~Hz}, \mathrm{H}-5)$, 5.46 (1H, dd, $J=15.1,7.3 \mathrm{~Hz}, \mathrm{H}-4), 5.34(2 \mathrm{H}, \mathrm{t}, J=4.9 \mathrm{~Hz}$, H-14, 15), 4.07 (1H, dd, $J=7.3,7.3 \mathrm{~Hz}, \mathrm{H}-3), 3.98$ (1H, dd, $J=7.8,3.9 \mathrm{~Hz}), 3.84(1 \mathrm{H}$, ddd, $J=7.3,4.9,3.9 \mathrm{~Hz}, \mathrm{H}-2)$, $3.78(1 \mathrm{H}, \mathrm{dd}, J=11.2,4.9 \mathrm{~Hz}, \mathrm{H}-1), 3.66(1 \mathrm{H}, \mathrm{dd}, J=11.2$, $3.9 \mathrm{~Hz}$ ), 2.02 (4H, m, H-13, 16), 2.01 (2H, m, H-6), 1.70 (1H, m, H-3'), $1.54\left(1 \mathrm{H}, \mathrm{m}, \mathrm{H}-3^{\prime}\right), 1.42-1.28(46 \mathrm{H}, \mathrm{m}$, $\left.-\mathrm{CH}_{2}-\right), 0.89$ (6H, t, $\left.J=5.9 \mathrm{~Hz}, \mathrm{H}-16,, 18\right) ;{ }^{13} \mathrm{C} \mathrm{NMR}$ $\left(\mathrm{CD}_{3} \mathrm{OD}, 125 \mathrm{MHz}\right) \delta 177.1\left(\mathrm{C}, \mathrm{C}-1^{\prime}\right), 134.9(\mathrm{CH}, \mathrm{C}-5)$, 131.1 (CH, C-4), 130.8 (CH, C-14, 15), 73.3 (CH, C-3), 73.0 $\left.\mathrm{CH}, \mathrm{C}-2^{\prime}\right), 62.0\left(\mathrm{CH}_{2}, \mathrm{C}-1\right), 56.0(\mathrm{CH}, \mathrm{C}-2), 35.9\left(\mathrm{CH}_{2}, \mathrm{C}-\right.$ $\left.3^{\prime}\right), 33.5\left(\mathrm{CH}_{2}, \mathrm{C}-6\right), 30.9-30.5\left(\mathrm{CH}_{2},-\mathrm{CH}_{2}-\right), 28.2\left(\mathrm{CH}_{2}, \mathrm{C}-\right.$ $13,16), 14.5\left(\mathrm{CH}_{3}, \mathrm{C}-16\right.$ ', 18$)$; HRFAB-MS $[\mathrm{M}+\mathrm{Na}]^{+} \mathrm{m} / z$ $630.5438(\Delta+0.1 \mathrm{mmu})$.

Acetyl derivative of $3 \mathrm{a}:[\alpha]_{\mathrm{D}}^{25}-7.2^{\circ}\left(\mathrm{c} 0.16, \mathrm{CHCl}_{3}\right) ;{ }^{1} \mathrm{H}$ $\mathrm{NMR}\left(\mathrm{CDCl}_{3}, 500 \mathrm{MHz}\right), \delta 5.79(1 \mathrm{H}$, ddd, $J=15.2,6.8,6.8$ Hz, H-5), 5.65 (1H, d, $J=9.5 \mathrm{~Hz},-\mathrm{NH}), 5.37$ (1H, dd, $J=$ 15.2, $6.8 \mathrm{~Hz}, \mathrm{H}-4), 5.29$ (1H, dd, $J=6.8,6.8 \mathrm{~Hz}, \mathrm{H}-3), 4.43$ (1H, m, H-2), 4.31 (1H, dd, $J=11.3,5.8 \mathrm{~Hz}, \mathrm{H}-1), 4.04(1 \mathrm{H}$, dd, $J=11.3,3.9 \mathrm{~Hz}, \mathrm{H}-1), 2.07$ (6H, s, $\left.\mathrm{CH}_{3} \mathrm{COO}\right), 1.99(3 \mathrm{H}$, $\mathrm{s}, \mathrm{CH}_{3} \mathrm{CONH}$ ).

Acknowledgment. This research was financially supported by the Korea Science and Engineering Foundation (No. R01-2001-000-00211-0) and MarineBio21, Ministry of Maritime Affairs and Fisheries, Korea.

\section{References}

1. Blunt, J. W.; Copp, B. R.; Munro, M. H. G.; Northcote, P. T.; Prinsep, M. R. Nat. Prod. Rep. 2003, 20, 1-48.

2. Higuchi, R.; Jhou, J. X.; Inukai, K.; Komori, T. Liebigs Ann. Chem. 1991, 745-752.

3. Iorizzi, M.; Minale, L.; Riccio, R.; Yasumoto, T. J. Nat. Prod. 1993, 56(10), 1786-1798.

4. Jin, W.; Rinehart, K. L.; Jares-Erijman, E. A. J. Org. Chem. 1994, 59, 144-147.

5. Ojika, M.; Yoshino, G.; Sakagami, Y. Tetrahedron Lett. 1997, 38, 4235-4238.

6. Venkannababu, U.; Bhandari, S. P. S.; Garg, H. S. Liebigs Ann./ Recueil 1997, 1245-1247.

7. Jarvis, W. D.; Kolesnick, R. N.; Fornari, F. A.; Traylor, R. S.; Gewirtz, D. A.; Grant, S. Proc. Natl. Acas. Sci. U. S. A. 1994, 91, 73-77.

8. (a) Horn, D. H. S.; Pretorius, Y. Y. J. Chem. Soc. 1954, 14601464. (b) Liu, J.; Hu, L.; Dong, Z. Lipids 2003, 38(6), 669-675.

9. Chakrabarty, M.; Batabyal, A.; Barua, A. J. Nat. Prod. 1994, 57(3), 393-395.

10. Diaz de Vivar, M. E.; Selders, A. M.; Maier, M. S. Lipids 2002, 37(6), 597-603

11. (a) Kawano, Y.; Higuchi, R.; Isobe, R.; Komori, T. Liebigs Ann Chem. 1988, 19-24. (b) Loukaci, A.; Bultel-Ponce, V.; Longeon, A.; Guyot, M. J. Nat. Prod. 2000, 63, 799-802.

12. Kim, Y.-A.; Park, M.-S.; Kim, Y. H.; Han, S.-Y. Tetrahedron 2003, 59, 2921-2928. 